\title{
Ayurveda and the medical knowledge in ancient India: Shadows and realities
}

CD SEBASTIAN

\begin{abstract}
Ayurveda is the Indian system of professional medicine that has come down to us from ancient times. In this paper, I look at the system from a researcher's point of view, critically examining the given or perceived view on Ayurveda in recent times. In this sense, it might look like a contrarian view or counter position to the narrative that one sees around with regard to its origin, place of origin, date, non/religious background, etc. The paper deals with Ayurveda as an independent tradition of medicine sans ascription to any religion, the possible influences of other systems on Ayurveda, and the three great luminaries of the system, namely, Caraka, Susruta, and Vagbhata.
\end{abstract}

Keywords: Ayurveda, Caraka, Indian medicine, Susruta, Vagbhata.

\section{Prologue}

Ayurveda is the ancient Indian system of medicine literally meaning "the knowledge of healthy long life." Ayurveda is concerned with "the 'total way of life,' and is not just a 'system of medicine' that offers to cure diseases through drugs and rituals."(1) According to the ancient physicians, in the "knowledge of healthy long life," medicine was not just the medical drugs used in the treatment of illness. "Medicine in their eyes was not a catalogue of makeshift devices to get over disease and re-establish bodily ease, but it was the synthetic facts underlying and regulating the life of [the hu]man in its varied physical, physiological and psychical aspects and stages, in a word, the science of life as a whole."(2) Caraka defines Ayurveda in this way: "The measuring (assessing) of that healthy long life (longevity) on

Author: CD Sebastian (sebastian@iitb.ac.in) Professor of Indian Philosophy, Department of Humanities and Social Sciences, Indian Institute of Technology Bombay Mumbai 400076 INDIA.

To cite: Sebastian CD. Ayurveda and the medical knowledge in ancient India: Shadows and realities. Indian J Med Ethics. 2022 Jan-Mar; 7(1) NS: 8-15. DOI: 10.20529/IJME.2021.085.

Published online on November 12, 2021.

Manuscript Editor: Sunita VS Bandewar

Peer Reviewers:Two anonymous reviewers.

(c) Indian Journal of Medical Ethics 2022 the basis of that which is beneficial and unbeneficial to healthy life, favourable (happy) and unfavourable (sorrowful) to healthy life, the wholesome and the unwholesome to healthy life, is called Ayurveda."1 (1: 1:41) (3). Thus, to put it simply, Ayurveda is the knowledge of healthy long-life $[a y u h+$ veda $=$ knowledge of (healthy long) life or "the science of longevity" (4)].

Caraka, Susruta, and Vagbhata are the three great teachers of Ayurveda. The legendary sage, Atreya, has been regarded as the initiator of the Ayurveda tradition; and some argue that Caraka owes a great deal to Atreya, a historical figure who flourished at Taksasila (Taxila). It is said that Atreya had six disciples - Agnivesa, Bhela, Jatukarna, Parasara, Harita, and Ksarapani - who in turn wrote medical treatises (samhita) and developed six schools of medicine. Among them, it is said, Agnivesa's Samhita was the most profound and highly regarded, and the Caraka-samhita might be, in all probability, indebted to Agnivesa's Samhita.

I look at the system of ancient medicine from a researcher's point of view, critically examining the given or perceived view on Ayurveda in recent times, in terms of policy and politics. In this sense, it might look like a contrary or counter position to the narrative that one comes across with regard to its origin, place of origin, date, non/religious background, etc. The products and produce from nature - including plants, animals, and minerals - have been the source of remedies and treatment for diseases in humans, animals, and plants ever since the origin of humanity. This paper deals with Ayurveda as an independent tradition of medicine sans an ascription to any religion, with the possible influences of other systems on Ayurveda, and the three great masters of the system, namely, Caraka, Susruta and Vagbhata.

\section{Ayurveda: An independent tradition of medicine}

The present author is of the opinion that Ayurveda has had a non-Vedic origin, though Vedic traditions contributed to it substantially, in its long trajectory of medicinal growth as a system. There was a brahmanisation of Indian medicine in due course, by the transformation of the heterodoxy into orthodoxy (5). In all probability, it was an independent and indigenous medicinal and therapeutic tradition in ancient 
India, without ascription to any religion. The specialised vocabulary pertaining to medicine was developed by the healers who mastered the art of curative methods. The healers, in all probability, must have come from agrarian communities and the ascetic fraternity, definitely not from a priestly or royal background (6); and by adding their knowledge of the local flora and fauna, improved the healing techniques that they had gained by observation. As far as my knowledge goes, in the brahmanic tradition of study, Ayurveda and Atharvaveda are later additions (even among the Vedas, only the Vedatrayi have precedence and primacy). It is said that "the inclusion of both Ayurveda and Atharvaveda in the enumeration of sacred brahmanic literature already reflects the incorporation of spurious traditions into [the] orthodox brahmanic system." (6: p 47). And this could be a verity, as "myth of descent, a narrative that can serve to integrate diverse groups" (7) was part and parcel of the brahmanic tradition.

\section{Ayurveda and Sramana parampara}

In continuation of what we have said earlier, originally in all probability, medicine and medical practice were part of the ascetic-based religious movement, the Sramana parampara (Jains, archaic Sankhya, Ajivikas, Ajnanavadins, Buddhists, and the Tantrik tradition), which antedates the Vedic tradition the Rsi parampara. Ayurveda is an old tradition; and the "systematic compilations of medical knowledge were prevalent before the time of Gotama, the Buddha (563-483 $\mathrm{BC})$. Indeed, the very presentation of Buddhist ideas in the older literature (for example, the Dhammacakkappavattanasutta of the Samyutta-nikaya or the Malunkyaputta-sutta of the Majjhima-nikaya with their emphasis on existential disease or injury, its diagnosis, its prognosis, and treatment) suggests that some sort of systematic medical tradition(s) was (were) widely known and respected."(8) When it comes to the Buddhist contribution to the discipline of Ayurveda, a learned scholar writes:

Medicine evolved along with the sangha and Buddhist monastery in India, became codified as a part of the Buddhist scriptures, gave rise to monk-healers ${ }^{2}$ and provided the basis for subsequent development of Buddhist monastic hospices and infirmaries, and finally became part of the standard curriculum in the Buddhist monastic 'universities'. When Buddhism began to spread to other parts of Asia, medical institutions and practices of the monastery went along as integral parts of the religious system. The traditional system of Ayurvedic medicine owes much of its early systematization, preservation, and subsequent propagation to the ascetic Buddhists and their monastic institution. (6: $p$ 48-9)

We get details of ancient medicinal practices from the oldest of the Buddhist canons, namely, the Vinaya Pitaka. In the surviving versions of the Vinaya Pitaka, namely, the Theravada Bhesajjakkhandhaka, the Dharmaguptaka Bhaisajyaskandhaka, the Mahisasaka Bhaisajyadharmaka, the
Sarvastivada Bhaisajyadharmaka, the Mulasarvastivada Bhaisajyavastu, and the relevant parts of the Mahasanghika Vinaya, we get details of medicaments. In the discussions found in the above mentioned portions of the Buddhist literature, we come across the Buddha allowing everything (9), except for human flesh 3 (10), for medical treatment. The Buddha had no regard for the brahmanical law-makers, but "on the contrary, many passages in the early Buddhist literature show his pronounced enthusiasm for medicine."(11) Hence, one would be prepared to propose that the discipline of medicine had much more to do with the non-Vedic lineages. Besides that, the famous Jivaka (or Jivaka Komarabhacca), who had studied at the medical school of Taxila (12) in the sixth century BC (13) (and became the personal physician of the Buddha), and the Buddhist tradition of specially selected and trained monks for the task of medical practice, give credence to the nonVedic ancestry of Ayurveda. We read in the Vinaya, that the Buddha instructed the monks to act as physicians (14). The Buddhist tradition sets a very high standard for a practising physician or surgeon as we see in the Buddhist text, the Milinda Panho (15), which shows its familiarity and expertise with both the nuances of treatment and nature of medicines (16).

The present author is not in agreement with the perceived view of many an Indian writer that Aurveda has its roots in the Vedas. One author writes: "To the critical student, the Vedas, which form the holiest of Hindu scriptures, are known to be important treatise on medicine and surgery, the Rigveda dealing mainly with the former and the Yajurveda and Atharvaveda with the latter. These three Vedas are the principle sources of Ayurveda. With these as foundations, fundamental treatises of Ayurveda have been written by Charaka, Susruta, and Vagbhata."(2: p177). His assertion is far from the truth, as far as the present author's study informs him. According to Manu, the physician's profession for livelihood was too demeaning for a dvija ("twice born," a term used for the three upper varnas), and it was allowed only in exceptional cases and in conditions causing dire distress ${ }^{4}$ (11). Further, as an example from the text, let us take the case of cow meat prescribed as medicine in chapter 27 of Sutra-sthana of Caraka samhita. According to the brahmanic texts, slaughtering the cow is a great sin, which demands prolonged penance (17), but the Ayurveda tradition appears to be advocating the consumption of it ${ }^{5}$ (I: 27: 79-80) (3). Thus, notwithstanding the fact that the brahmanic law-givers espoused the veneration of the cow, "the genuine physicians in our medical compilation appear to remain unconcerned. What interests them is a different point altogether. It is only the food-value of the cow's flesh, like that of the flesh of various other animals, for they think that the most important factor determining health is food."(18) In this regard Francis Zimmermann's erudite study on "meat, medicine and ecology"(19) in Ayurveda supports the submission we make. We will explain it further in the following. 


\section{Ayurveda and the Agama tradition}

Ayurveda is an Agamic tradition, not Vedic. Today, though, many scholars try their best to place its origin in the Vedic tradition, to state that all that is good and worthwhile came from Vedic traditions, and not from non-Vedic sources. Surprisingly, the Buddhist Vagbhata is presented now by some as a Vedic Rsi. Even the learned writer MS Valiathan tries to show that Vagbhata's roots are Vedic, misinterpreting the use of the term "agama" by Vagbhata in his text, as of "Vedic origins." In the text, Vagbhata says: "This (text/knowledge) (idam) has come down to us as proven remedies from the respected tradition of medicinal practice (agamasiddhatvat) and, as seen and verified by perceivable (real) results (pratyaksaphaladarsanat), it could be applied (made use of) (samprayoktavyam) as an authoritative and established formula (canon) (mantravat), and not as a mere hypothesis of investigation (mimamsyam) by some means haphazardly (kathancana)." 6 (20) This verse has been translated by MS Valiathan in this manner: "Born of Vedic origins and of demonstrable results, this text is fit to be used as a mantra with no room whatever for doubting its efficacy."(21) One wonders whether Valiathan's translation is correct and, more than that, whether the term agama can be translated as "Vedic origins." I must state that in the Indian philosophical cum cultural tradition, the term "agama" stands mainly for nonVedic tradition that has come down to us from generation to generation. This is what PP Narayanan Nambudiri says about it: "The Hindu religious tradition, philosophy, practices, and ritual fall under two categories - the Nigama and the Agama, Nigama stands for the Vedic, the Karmamarga, the Homa or the sacrifices which is of the Aryans. The first origin of the Agamic Cult was non-Aryan and Pre-Aryan. It was later modified, extended, and adopted by the brahmans for the sake of all, while the Homa or Nigama was kept up artificially for limited group of Aryans."(22) Thus, as Vagbhata asserts, I would hold that the Ayurveda is of agamic tradition and not of nigamic (Vedic) tradition.

\section{Ayurveda and the Indus Valley - Mesopotamian connection}

It is fascinating for a student of Indian philosophy and culture to learn about the healthcare system in the Indus Valley civilisation. Analysing the modes of hygiene and other information that one finds in "the ruins of the extremely large town excavated at Mohen-jo-daro," Jean Filliozat writes in his The Classical Doctrine of Indian Medicine: Its Origin and its Greek Parallels, that they "are particularly remarkable in view of the uncovered remains of the large-scale works of public sanitation." (4: p 32) And he concludes that there was a preAryan medicinal practice in the Indus Valley in the third millennium $B C$, as there could have been an exchange of medicinal knowledge "between Mesopotamia and the Indus Valley," as there had been "already developed medical notions, which were probably related to those of Sumerians", and that, in due course "at least ideas which have entered as elements in the formation of Ayurveda." (4: p 34)
The medical science of India must have had a strong connection to the North-West of India in ancient times. As mentioned earlier, the Buddha's physician Jivaka was trained at the famous university of Taxila (Taksasila) "Atreya, whose doctrines are propagated in the CaS (Caraka-samhita), lived at Taksasila."(23) There probably was an unbroken connection of the old Gandhara tradition to Indian medicine."It would seem that from the north-west, i.e., from the Gandhara country, the sciences were transferred to the east, and among them medicine as well as surgery." (23: p 324)

The Caraka-samhita is assumed to have been redacted in the first two or three centuries of our era (24). The redacted texts that are available now, particularly the Caraka-samhita and Susruta-samhita, mention the Atharvaveda as the source of Ayurveda and treat it as an upanga or subsidiary to the Atharvaveda. The Susruta-samhita 1:1:3 says that Ayurveda is a subsidiary part of the Atharvaveda (Ayurveda nama yad upangam atharvavedaya), and the Carakasamhita 1: 30:20 (3) says that the physician should have devotion to the Atharvaveda which, among the four Vedas, belongs to him appropriately (bhisaja...vedanam atmano'tharvavede bhaktir adesya). In all probability, this Atharvaveda connection could be a later addition. I suggest this because the three samhitas of Ayurveda are "of Bhela, Caraka, and Susruta. The first has reached us in one single and incomplete manuscript. The other two are not available in their original form because we know that they have been revised by more recent authors." (4: $p$ 1) The texts mentioned above had many redactions till they reached the present form (24), and they "were at least substantially reworked as late as the ninth or tenth centuries." (25) The science of medicine was a rationalistic endeavour, and the law-makers (of the Dharmasastras) were "sharply against the doctors;" and the Ayurvedic doctors had to make compromises in the compilations of the texts "to evade the censorship of the law-makers" by accepting "the absolute validity of the Vedas." (11: pp 137-8) It must also be mentioned that, theoretically and textually, Ayurveda consists of eight members (divisions) or astangas, which has much to do with the Astanga-samhita and the Astangahrdaya of Vagbhata. Even the traditional Ayurveda physicians of Kerala maintain that they are in the lineage of asta-vaidyas (26).

\section{Influence of other systems on Ayurveda}

The naturalistic philosophical traditions of India must have had a significant influence on Ayurveda. It is a verity that "medicine was the most important of all physical sciences" (27) in India, and Ayurveda took recourse to the naturalistic philosophical schools of India to lay bare the logical foundation of the system (27: 273-436). "The dominant intellectual influence on Ayurveda is that of Sankhya and Vaisesika philosophies." (8: p 247) The archaic Sankhya was such a robust naturalistic system that it interpreted the reality in terms of two categories, namely, 
"nature" (prakrti) with its evolutionary process, and the multiplicity of the "life principle" (purusa), without giving any credence to a creator God or supreme being. Similarly, the ancient Kanada tradition (Vaisesika) was more of a naturalistic system (whereas the Yajnavalkya tradition of the Upanisads was a spiritual system). Biswambhar Pahi, a preeminent contemporary scholar of Nyaya-Vaisesika, has given a pro-Carvaka (Lokayata) interpretation of the Vaisesika system(28). The Sankhya influence on Ayurveda could be seen in "the formative elements of the universe." (4: p 26) There were mutual interactions among rational and naturalistic philosophical systems of India and Ayurveda, and "one can argue that there was a natural affinity between the naturalistic philosophical systems and Ayurvedic medical practice which generated a mutually influential pattern of ongoing interaction." (8: p 248) The "naturalism" (svabhavavada) that one finds in Indian tradition is non-Vedic as observed by M Hiriyanna: there are two currents of thought in the "early post-Vedic period," namely, the one known as Svabhavavada or "naturalism" which repudiated belief in the supernatural and the other "naturalism," which was dualistic or pluralistic in its character and gave rise to the "naturalism" that we find in Jainism (29). Therefore, I submit that the "naturalism" in Indian thought ran parallel to the Vedic "supernaturalism" of the ancient period.

In the Caraka-samhita 1:1:42 (3), it is said: Life (ayuh) comes into existence due to the association of the body (sarira), senses (indriya), mind (sattva or manas), and soul (atma). In the first part of the Caraka-samhita called the Sutra-sthana (Caraka-samhita 1: chapters 1-30), one finds the metaphysics of Sankhya and Vaisesika systems dominating. The conceptions of purusa - an allembracing consciousness - and prakrti - the primordial materiality with its three gunas of sattva, rajas, and tamas (of the Sankhya) - and the substances (dravya) which make up the world - air, fire, water, earth, space, time, extension, mind, and self - and the six fundamental categories (padartha) by means of which everything is cognised - substance (dravya), property (guna), motion (karman), generality (samanya), particularity (visesa), and inherence (samavaya) of the Vaisesika - find a place in Ayurveda (8: pp 248-9). The tenets of Sankhya and Vaisesika systems get a place in Ayurveda,"for these systems appear to be most congenial to a naturalistic and common-sense approach to ordinary life and experience."(8: p 252) Gerald Larson says that the Ayurvedic medical theory and practice are "pragmatic and usage-oriented," and Sankhya and Vaisesika provide the most naturalistic interpretation in this sense, and they "are remarkably alike in their fundamental postulates," unlike other dasanas of Indian philosophy (8: p 252). Both Sankhya and Vaisesika are known for their analysis of the physical body, and they are more rational rather than spiritual and religious teachings. In Carakasamhita 1:11:3 it is said that the purpose of Ayurveda is directed toward three motifs: this-worldly natural search and desire for long life (pranaisana), moderately needed material wealth (dhanaisana), and good deeds that will facilitate a life after-death (paralokaisana), whereas the aim of the religious systems is to attain moksa (8: p 252).

Our discussion on Ayurveda and Sankhya is not complete unless we mention an important dissimilarity between the classical Sankhya and the Caraka-samhita. A learned scholar of the twentieth century, an expert on Sankhya and Caraka, VM Bedekar, has shown the main difference between the Caraka-samhita's twenty-four principles and those of classical Sankhya (30). "Caraka's scheme is in many respects, different from that of the classical Samkhya. The most glaring and fundamental difference consists in the fact that Caraka regards Avyakta as identical with Purusa, Atman or Brahman. Considering that Caraka's Avyakta gives rise to succeeding principles such as Buddhi, Ahamkara, etc., it may be stated that Caraka's Samkhya doctrine does not represent the fundamental Dualism of the Samkhya, but a sort of idealistic monism" (30: p 147).

One would also posit that there were influences of other naturalistic schools of thought on Ayurveda, particularly on Caraka. The Ajivikas, Carvaka (Lokayata), Jainism, even the Indian Sceptical school (Ajnanavada), whose most prominent teacher was Sanjaya, were Svabhavavadins (naturalists). There could also have been an influence of the theory of "accidentalism" (Yadrcchavada), a philosophical stance that upholds things happening accidently and not due to a causal connection to the effect. VM Kulkarni in his study had opined that the svabhavavada - naturalism doctrine is "part and parcel of materialism as has been done by tradition" (31). In his scholarly paper, Tabe E. Meindersma has shown how the ideas of Indian materialism (Carvaka) infiltrated the theories of Caraka (24). These schools of thought must have influenced Ayurveda in its formative years.

Caraka does not mention Yoga in his works. It is noteworthy that "Caraka's approach made no reference to Yogasanas or meditation as procedures in the practice of medicine," (32) as Caraka's intent was that the physical body shall be treated with medicine. And his treatment is efficacious to heal the body and mind of ailments. Today, Ayurveda practitioners combine Ayurveda and Yoga. But Caraka did never pay attention to Yoga practice. A sixteenth century (AD) text "the Ayurvedasutra," was "the first Sanskrit medical treatise said to combine the basic doctrines of both Ayurveda and Yoga into one text" (33).

\section{The Brhat-trayi of Ayurveda: Caraka, Susruta, and Vagbhata}

The Great Three (brhat-trayi) of Ayurveda are Caraka, Susruta, and Vagbhata. Caraka was the master physician, whereas Susruta was the surgeon par excellence. Vagbhata was both a great physician and surgeon. Let me give a brief account of these three masters with some contrapositions as the backdrop. 


\section{Caraka}

Caraka (Charak) has been considered the chief physician of Ayurveda. But there is a scholarly opinion that the term "caraka'" was used for "the wandering heretical ascetics" (34), who were not followers of the Vedic tradition but were "the wandering practitioners of the medical art" (34: p 109). If we take Caraka as a person, the dates assigned to him range from the second century $B C$ to the second century $A D$ when the Kusana Empire (35) flourished in North India. From the internal evidence in the Caraka-samhita, he seems to have lived in the North Western part of India in the post-Buddha period. C Kunhan Raja is of the view that "Caraka" was not a Sanskrit word but a Pahlavi word, Careka (36). It is interesting to note that "the Iranian people of Upper Asia and of Iran itself, the Sakas, the Parthians, and Kusanas conquered vast territories of India several times and stayed there as rulers for long periods" (4: p 35). So, was Caraka of that origin? In Arthasastra, the word "Caraka" was used for people considered inferior who were servants and attendants (37). In this connection, PV Sharma writes in his "Introduction" to the text, Caraka-samhita: "The probable connection of Caraka with Kaniska leads to some more important but hidden points. Kaniska belonged to the Kusana dynasty, which was an offshoot of Sakas who came to India roaming about from Central Asia.... In Nananitaka, Caraka is not mentioned as author of the text though Agnivesa is there and the followers of Caraka instead of having been assimilated in the general mass of vaidyas formed a separate group patronised by the Saka kings. All these facts indicate that Caraka was either himself a Saka or very close to them so that he had to struggle hard for putting his foot down. Perhaps during the same process, the work of Caraka (the Caraka-samhita) was mutilated, which was redacted and reconstructed by Drdhabala in part" (38). Whatever may be the facts with regard to his place, origin, and time, "what Caraka wrote continues to interest students and teachers of Ayurveda, practising physicians, pharmacologists, philosophers, historians of science, even patent lawyers" (32: p i).

\section{Susruta}

Susruta is associated with Kasi (Banaras or Varanasi). He was a master surgeon of Indian medical practice. When he lived has long been a controversial issue among many medical historians. It is said that he seemed to have lived and taught in Varanasi before the Buddha. It is said that Susruta studied Ayurveda with emphasis on Salya (surgery) under Divodasa Kasiraja Dhanvantari of the Upanisadic age (6th century BC). He composed the Susruta-tantra. Though the original text was lost long ago, a redaction by Nagarjuna survived as the Susruta-samhita, which was composed "either in the sixth or the tenth century A. D." (8: p 247). According to HG Ranade, the Susruta-samhita is of a later origin than that of the Carakasamhita. He writes, "Caraka Samhita roughly belongs to the 1 st cent. A. D. while the Susruta with its developed surgery is later in period" (39). He was the first to practise rhinoplasty in India. In the Susruta-samhita, we find the origin of surgery as in Kasi. In the Buddhist Jatakas, the surgery of "skull opening" was learnt by Jivaka in Taksasila, and "in the legend surgical training is expressly proved to have originated from Taksasila, this training is limited in the SuS (Susruta-samhita) to the king of Benares (Kasiraja)" (23: p325).

It is intriguing to posit the advancement of surgery in ancient Indian medical history as there must have been many obstacles that deterred the study of anatomy, if the Hindu Dharmasastras are taken into account. Furthermore, in neither the writings of Susruta nor of Caraka is there any indication that animal dissection was practised to learn anatomy. Their anatomical knowledge, therefore, appears to have been gleaned from human dissection (40). According to the Dharmasastras, the human body is sacred in/after death, and the body should not be violated by the knife, and that persons older than two years of age must be cremated in their original condition. The texts outlining household rituals - Grhyasutras (41) - assert the sanctity of the dead body and classify cremation as a samskara which assures "the third birth" for a dvija (twice-born, the three upper varnas). So the surgical learning by dissecting the corpse would be anathema as per the laws of the Dharmasastras. Indian surgical tradition overlooked those dictates, implying that the Indian surgical institution has much more to do with the non-Vedic traditions.

\section{Vagbhata}

Vagbhata is one of the most influential classical writers of Ayurveda. He was a physician, surgeon, poet, and teacher. "Among the ancient authorities of Ayurveda, Vagbhata stands out not only as a great physician and master teacher but also as a writer endowed with extraordinary literary skill and poetical gifts"(21: $p$ xviii). Several works are associated with his name as author, principally the Astanga-samgraha and the Astanga-hrdaya-samhita. Vagbhata was from the province of Sindh (42) or Kashmir. Analysing the family tree of Vagbhata from different manuscripts, D Wujastyk has shown the Sindh and Kashmir connection of Vagbhata. He writes "our present discovery shows the still untapped riches available in the manuscript record, and suggests that traditions lost elsewhere may still be available in manuscripts of Kashmir" (43).

Some scholars opine that there were two Vagbhatas, one senior and the other junior, and the text the Astangasamgraha belongs to Vagbhata, the senior, and the Astangahrdaya-samhita belongs to Vagbhata, the junior (44). Among the recent scholars, Kenneth G Zysk is of the opinion that these two classical medical treatises were composed by authors (not the same author) with the name Vagbhata. "The first by Vagbhata and the second by Vrddhavagbhata, 'the Elder Vagbhata.' It is unknown if these two Vagbhatas refer to the same person" (33: p S111). But Dinesh Chandra Bhattacharyya confirmed after analysing internal evidences in the texts and commentarial references in the commentaries that there was only one Vagbhata. He writes 
that "it should now be finally settled on clear and definite evidence that there was only one medical authority of the name of Vagbhata" (42: p116). Vayaskara NS Mooss, in his edited version of Astanga-hrdaya-samhita with the Vakyapradipika Commentary of Paramesvara, Part 1, after a careful evaluation of the texts and commentaries, holds that the author of Astanga-samgraha and Astanga-hrdaya-samhita was one and the same person (45). The present author also holds that there was only one Vagbhata, and not two.

There is strong internal evidence in his treatises indicating that Vagbhata was a Buddhist. However, some brahmanical writers of the past and present picture him as a Brahmana who followed Vedic religion (21). At the end of the second chapter of Cikitsasthanam in the Astanga-samgraha, we get the Buddhist faith of Vagbhata, and his allegiance to Tathagata (the Buddha). We quote the verse:

\section{Aryavalokitam caryo sabarimaparajitam, Paranamedaryataram ca sarvajvaranivrttaye. Japam tathagatosnisam sarvavyadhicikitsitam, Agantudosasahajaih sarvarogairvimucyate (46).}

[One should bow to noble Avalokita, noble undefeatable Sabari, and noble Tara ${ }^{7}$. By repeated (internal) uttering of the Buddha's crown of hair (usnisam) ${ }^{8}$ (47), which is all- illness curing panacea, one will get healed and saved from all diseases caused by the externally influencing dosas as well as the congenital ones.]

The commentator of the Astangasamgraha, Indu, whose commentary is much relied upon today tried to discard, it seems to the present author, the Buddhist elements from the text $(48,49)$. Surprisingly, the latest translation of Vagbhata's Astangasamgraha by KR Srikantha Murthy completely avoids the term "Tathagatosnisam" (the Buddha's crown of hair) as he translates the last verse quoted above. His translation goes like this: "By meditating upon and reciting the all disease curing 'Gatosnisa' hymn, man will get rid of all diseases, caused by the external agents, internal dosas and the congenital factors" (50). Dinesh Chandra Bhattacharyya analyses other commentaries on Vagbhata like those of Indu (eg: Tathagatosnisam nama mantravisesam), Cakrapanidatta, Candranandana, Niscalakara, Arunadatta, and others, and he writes: "This reference to the Buddhist God twelve-armed Avalokitesvara is very important as it proves that when Vagbhata wrote, Mahayana Buddhism had already reached its final stage in iconolatry. It is curious that the Kairali commentary on the above passage (published in the Trichur edition) explains the strange God as a form of Siva; ... But it can perhaps be confidently stated that no image of twelvearmed Avalokitesvara came to be worshipped so widely in India before the 9th century A. D., and 800 A. D. can be conveniently taken as the terminus a quo of Vagbhata's date" (42: p 124). What I wanted to state, at the end is that there has been a consistent apathy from the brahmanical interpreters and commentators towards the Buddhist contribution to Ayurveda.
The most important contribution of Vagbhata is that he digested ancient texts of Ayurveda - even those of Caraka and Susruta - and with his own experience and ingenuity redistilled them for the benefit of posterity. He "succeeded in giving us an admirable text which has never been exceeded in authority by anything written by his successors. But Vagbhata derives his majesty, above all, from his application of moral ideas to the practice of medicine" (21: $p$ xviii). He excels in addressing the moral question of "how to live" and practise the medical profession: as a true Buddhist, he urges compassion towards all living beings and identification of oneself with bugs and ants - every sentient being. Among all the teachers of Ayurveda, Vagbhata has this to say to a medical practitioner that "compassionate and pure mind cures all types" of sickness (51).

\section{Epilogue}

Ayurveda is a rational system where "experience" has manifestly played an important role. The Caraka-samhita and the Susruta-samhita "explain the state of health and of disease by the interplay of constituent elements of the organism, of the elementary and general regimes and by the influences of time and season," and they did not pay much attention to "magic and mysticism" (4: p 26). The system of treatment was based on experience, that is, "the rudiments of the natural explanation of a phenomenon or of a justification of an observed property" (4: p135). It was not dogmatic, but flexible.

Caraka must have lived in a time when intellectual life in India was very dynamic and vibrant. The orthodox schools of Indian philosophy (not Vedanta) were in varying stages of development, and the powerful opposition to them by the Ajnanavadin (Sceptics), Carvaka, Ajivika, Buddhist, and Jain intelligentsia was the mark of the time. There was an intellectual climate in India when ideas clashed, dogmatic orthodoxy and challenging heterodoxy confronted each other, systems were sharpened and redefined, and the old gave place to the new.

When it came to Vagbhata, he took the essentials of Buddhist philosophy where the life here and now was of paramount importance. The Buddhist conception of the body, which is sacred and treasured for spiritual practice (spiritual sadhana) is possible only when one has a healthy body, was taken into serious consideration. The metaphysics of the body, that is, the body is composed of the five elements ( panca-bhuta), and the idea of equality of bodies - there are neither high nor low bodies (due to birth/caste or gender) - took the upper hand. One needs a healthy body for a healthy mind. Body and mind are not separate entities in Buddhism, but are mutually dependent. Suffering, due to physical and mental ailments, being a fundamental truth of the human existential predicament, the finest minds of Indian medicine and healing sought for a system, which would heal maladies, paving the way for a healthy long life. 
Acknowledgments: The author would like to thank the two unknown reviewers. One of the reviewers had recommended the paper as it was in the first draft. The present version is the revised and modified one in the light of the comments and observations made as per the other reviewer's recommendation.

\section{Notes:}

${ }^{1}$ Hitahitam sukham duhkhamayustasya hitahitam,

Manam ca tacca yatroktamayurvedah sa ucyate. (I) 1:41. (3)

2 The notion of 'Bhaisajyaguru' who is the 'Medicine Buddha', curing all sorts of suffering using his teaching in Mahayana Buddhism, inspired Buddhists to practise medicine. A Sanskrit manuscript of the Bhaisajyaguru-vaidurya-prabha-raja Sutra was among the texts attesting to the popularity of Bhaisajyaguru in the ancient northwest kingdom of Gandhara (today's Peshawar area) which included Taxila.

${ }^{3}$ The "Nidanas of the Vinayas, which in the section on remedies (Bhaissjya) forbid monks to use human flesh." (10)

4 "According to Manu... Only under exceptional conditions causing dire distress, the law-giver grudgingly allows the dvijas to go for these. Their list, as given by the law-giver, is: vidya silpam bhrtih seva goraksam vipanih krsih, i.e, learning crafts, wage-earning, servitude, cattle-raising, shop-keeping, agriculture. ... The vidya or learning is to be understood here in a specific sense.... As Kalluka Bhatta very pointedly says: vidya vedavidya-vyatirikta-vaidyatarka visapanayana-adi-vidya - "by learning is meant here those specific forms of learning which are different from the learning of the Vedas, as for example the kind of learning cultivated by physicians, logicians, poison-removers, etc." (11).

${ }^{5}$ The text says that the flesh of the cow is beneficial for those suffering from loss of flesh due to disorders caused by an excess of vayu, rhinitis, irregular fever, dry cough, fatigue, and also in cases of excessive appetite resulting from hard manual work (3).

${ }^{6}$ Idamagamasiddhtvat-pratyksaphaladasanat, Mantravat-samprayoktavyam na mimasyam kathancana (Astangahrdaya, Uttarasthana (VI) 40:81 (20)

7 In Mahayana sutras, Avalokita is Avalokitesvara, one of the eight great Bodhisattvas, who is the embodiment of compassion, Tara is closely associated with Avalokitesvara, the Bodhisattva of compassion; while Sabari, in Buddhist iconography, is the sixth of the eight goddesses (Gauri) who holds Meru mountain in her right hand and cannot be defeated by any evil forces.

${ }^{8}$ In the Buddhist literature, art, and iconography, Usnisam is the crown of hair, the three dimensional oval at the top of the head of the Buddha. In Mahayana Buddhism, the Buddha's crown of hair - Tathagata-usnisa - is a point of meditation as it is one of the thirty-two marks of the greatness of the Buddha (mahapurusa-laksanani) as seen in the Ratnagotravibhago Mahayanottaratantrasastra 3: 23). It symbolises the highest spiritual endowment of the Buddha and also his loving kindness to all sentient beings. It emits numerous rays (rasmi) which have miraculous powers to heal, protect and save (47).

\section{References}

1. Satyavati CV. The Role of Ayurveda as Contemporary Medical Science and Therapeutic System. I/C Quarterly. 1991; 18 (2-3):71-82.
2. Ayyar PR. The Eternal Glory of Ayurveda. Curr Sci. 1946; 15 (7): 177.

3. Sharma PV, (ed), The Caraka-Samhita - Sutrasthanam (I) 1: 41. Text with English Translation. Varanasi: Chaukhamba Orientalia, 2014:6.

4. Filliozat J. The Classical Doctrine of Indian Medicine: Its Origin and its Greek Parallels. Delhi: Munshiram Manoharlal Publishers, 1964: 1.

5. Zysk KG. Mythology and Brahmanization of Indian Medicine: Transforming Heterodoxy into Orthodoxy. In: Josephson F, (ed). Categorization and Interpretation: Indological and Comparative Studies. Goeteborg: Department of Comparative Philosophy, Goeteborg University, 1999:125-145.

6. Zysk KG. Asceticism and Healing in Ancient India: Medicine in the Buddhist Monastery. Delhi: Motilal Banarsidass, 1998: 21-37.

7. Figueira DM. Aryans, Jews and Brahmins: Theorizing Authority through Myth of Identity. Albany: State University of New York Press, 2002: 3.

8. Larson GJ. Ayurveda and the Hindu Philosophical Systems. Philos East West. 1987, 37 (3): 246.

9. Masahiro S. On flesh as medicine in the Nikaya period [Buha ni okeru 'yaku'to shite nikushoku no shoso]. In Sengaku M, (ed), Ga no shiso: vol. Tokyo: Shunjusha, 1991:543-554.

10. Durt H. Two Interpretations of Human-Flesh Offering: Misdeed or Supreme Sacrifice. In Williams $\mathrm{P}_{\text {, (ed). Buddhism: Critical Concepts in }}$ Religious Studies. Vol. VIII. London and New York: Routledge, 2005: 117-136. See $\mathrm{p} 119$.

11. Chattopadhyaya DP. A Critical Analysis of the Medical Compilations. In his: Science and Philosophy in Ancient India. Delhi: Aakar Books, 2013: 143.

12. Mueller RFG. The medicine of the Jatakas: A study of the history of medicine [Die Medizine der JAtaka's: eine medizingeschichtliche Studie] Janus; 1928: 32: 255-77. See p. 276.

13. Chen TSN, Chen PSY. Jivaka, Physician to the Buddha. J Med Biography. 2002; 10a: 88-91.

14. Rhys Davids TW, Oldenberg H, (tr). The Vinaya Texts. Delhi: Satguru Publications; 2003:Vol Il: 241.

15. Rhys Davids TW, (tr). Milinda Pañho: The Questions of King Milinda. In: The Sacred Books of the East. Vol. 35, Part II. Delhi: Motilal Banarsidass Publishers, 2003:254-5.

16. Thakur VK. Medical Sciences and the Buddhist Tradition: A Note on the Milinda Panho. Proceedings of the Indian History Congress. 2000-2001; 61 (1): 103-10.

17. The Manusmti. XI:79; XI:60; XI: 109-117.

18. Chattopadhyaya DP. Tradition of Rationalist Medicine in Ancient India. In his: Science and Philosophy in Ancient India. Delhi: Aakar Books; 2013: 103.

19. Zimmerman F. The Jungle and the Aroma of Meats: An Ecological Theme in Hindu Medicine. Delhi: Motilal Banarsidass Publishers; 1999. pp 96-205.

20. Srikantha Murthy KR. Vagbhata's Astanga Hrdayam. Notes; Vol 3. Varanasi: Chowkhamba Krishnadas Academy;2021: p 429.

21. Valiathan MS. The Legacy of Vagbhata. Hyderabad: University Press; 2009: See: Quotes from Vagbhata verse 68.

22. Nambudiri PPN. Bhakti Cult in Kerala. Proceedings of the Indian Historical Congress. 1981;42:157-8.

23. Mueller RFG. On an Origin of the Caraka and Susruta Sanhitas. Journal of the Royal Asiatic Society of Great Britain and Ireland. 1933, 2: 323.

24. Meindersma TE. Caraka and the Materialists. [Wiener Zeitschrift fur die Kunde Sudasiens]. Vienna Journal of South Asian Studies. 1992, 36. (Supplement: Proceedings of the VIII World Sanskrit Conference, Vienna; 1990): 300

25. Engler S. 'Science' vs 'Religion' in Classical Ayurveda. Numen. 2003;50 (4): 420.

26. Mooss NS. The Lalita Vyakhya of Astanga-Hrdaya. Annals of the Bhandarkar Oriental Research Institute. 1950; 31 (1/4): 274.

27. Dasgupta SN. A History of Indian Philosophy. Vol. 2. Delhi: Motilal Banarsidass Publishers; 2006: 273.

28. Gokhale P. Professor Biswambhar Pahi: The Nyaya-Vaisesika Reformer. In: Sharma RP, Varshney A, (eds.). Philosophical Thoughts of Professor Biswambhar Pahi: Critical Reflections. Jaipur: Department of Philosophy, University of Rajasthan. (pp. 19-30). Available from: https://www.academia.edu/38868294/ Professor_Biswambhar_Pahi_The_Ny\%C4\%81yaVai\%C5\%9Be\%E1\%B9\%A3ika_Reformer accessed on 15 May 2020.

29. Hiriyanna M. Popular Essays on Indian Philosophy. Mysore: Kavyalaya Publishers; 1952.110.

30. Bedekar VM. Studies in Samkhya: Pancasikha and Caraka. Annals of the Bhandarkar Oriental Research Institute. 1957;38 (1-2): 143.

31. Kulkarni VM. Svabhavavada (Naturalism): A Study. In: Upadhye AM, 
et al, (eds), Sri Mahavira Jaina Vidyalaya Suvarna Mahotsava Grantha. Bombay: Sri Mahavira Jain Vidyalaya, 1968: 18

32. Valiathan MS. The Legacy of Caraka. Chennai: Orient Longman, 2006: ix.

33. Zysk KG. The Bodily Winds in Ancient India Revisited. Journal of the Royal Anthropological Institute. 2007, 13: S112.

34. Meulenbeld GJ. A History of Indian Medical Literature. Vol.1, Part 1. Groningen: Egbert Forsten, 1999: 107.

35. Benjamin C. Empires of Ancient Eurasia: First Silk Road Era, 100 BCE 250CE. Cambridge: Cambridge University Press, 2018: 176-203.

36. Kunhan Raja C. Survey of Sanskrit Literature. Bombay: Bharatiya Vidya Bhavan; 1962: 277.

37. Kangle RP. The Kautilya Arthasastra: Sanskrit Text with Glossary. Part 1. Delhi: Motilal Banarsidass Publishers, 2014; 59: 130).

38. Sharma PV. Introduction. In: Sharma, PV (ed). Caraka Samhita: Text with English Translation, Vol. 1, Sutrasthana to Indriyasthana. Varanasi: Chaukhambha Orientalia, 2014: viii-ix.

39. Ranade HD. Woman in the Ayurvedic Literature. Bulletin of the Deccan College Post-Graduate and Research Institute. 1970-21 - 1971-72;31/32 (1- 2): 317.

40. Loukas M, Lanteri A, Ferrauiola J, Tubbs RS, Maharaja G, Shoja MM, et al. Anatomy in Ancient India: a Focus on the Susruta Samhita. $J$ Anat. 2010; 217 (6): 646-50.

41. Vidyaratna RN, Vedantavagisa AC, (eds). Grahyasutra of Asvalayana with the Commentary of Gargya Narayana. Calcutta: Baptist Mission
Press; 1869:4:3-16;4:4:7.

42. Bhattacharyya DC. Date and Works of Vagbhata the Physician. Annals of the Bhandarkar Oriental Research Institute. 1947; 28 (1-2): 122.

43. Wujastyk D. Ravigupta and Vagbhata. Bulletin of the School of Oriental and African Studies. 1985,48 (1): 78.

44. Hoernle AFH. Itsing and Vagbhata. Journal of the Royal Asiatic Society of Great Britain and Ireland. 1907: 414

45. Mooss NS, (ed). Astanga-hrdaya-samhita with the Vakyapradipika Commentary of Paramesvara, Part 1. Kottayam: Vidyasarathy Press 1950.

46. Vagbhata. Astangasamgraha, Vol. 2. Mumbai: Atmaram; printed at Ganapata Krishnaji Mudranalaya, 1888: 15

47. Johnston $\mathrm{EH}$, (ed), Ratnagotravibhago Mahayanottaratantrasastra. 3: 23. Patna:The Bihar Research Society, 1950, p. 95

48. Shubaktha PKJP. Indu and Bhattanarahari - The Commentators of Ayurvedic Classical Treatises. Bull Indian Inst Hist Med. 2001: XXXI (2): 156.

49. Gode PK. Chronological Limits of the Commentary of Indu on the Astangasamgraha of Vagbhata I. Annals of the Bhandarkar Oriental Research Institute. 1944: 25 (4): 223.

50. Srikantha Murthy KR, (tr). Astanga Samgraha of Vagbhata. Varanasi: Chaukhambha Oreintalia, 2018: 289.

51. Srikantha Murthy KR, (tr). Vagbhata's Astanga Hrdayam, Vol. 2, Varanasi: Chowkhamba Krishnadas Academy,2021:203-4.

\section{The FMES is supported by occasional grants from philanthropists and subscriptions to the journal.}

\section{APPEAL FOR DONATIONS TO THE FORUM FOR MEDICAL ETHICS SOCIETY}

The Indian Journal of Medical Ethics (IJME), now approaching its 30th year, has been published by the Forum for Medical Ethics Society (FMES) since 1993. IJME is a multi-disciplinary academic journal providing a platform for original content and discussion on all aspects of healthcare ethics, as well as law, history, literature, philosophy and the humanities where they intersect with health and healthcare. We are committed to maintaining our editorial independence which is critical to safeguarding the scientific integrity of what we publish. Therefore, wider support from all those who are committed to social justice in health is essential.

FMES is registered under the Societies Registration Act, 1860 and the Bombay Public Trusts Act, 1950. Donations are eligible for tax exemption under Section 80G of the Income Tax Act, 1961. Donations are solicited only from Indian individuals and entities, as donations from foreign individual/entities are not permitted under Indian law. However, foreign readers/authors may wish to support the journal by:

- Gifting subscriptions to the print or soft PDF copies of the journal;

- voluntarily paying any amount for full text views of individual online articles or PDF downloads;

- Or paying a fee for article processing when submitting an article to be considered for publication

- For more details on how to support us, write to admin@ijme.in or visit our website

www.ijme.in/subscribe-support/ Support open access academic publications, donate to the FMES, corpus for the publication of IJME! 